\title{
The Predictive Role of Teacher Candidates' Life Satisfaction and Communication Skills on Academic Success
}

\author{
Bünyamin ATEŞ1 $\quad$ Mehmet Enes SAĞAR ${ }^{2}$
}

\begin{abstract}
In this study, the predictive role of life satisfaction and communication skills variables on teacher candidates' academic achievement teacher candidates was examined. The research was conducted based on the relational screening model. The research group consisted of 398 teacher candidates (172 males, 226 females) studying at the education faculties of different universities in Turkey in the 2020-2021 academic year. The age range of the teacher candidates in the study is between 18-25; the average age was determined as 21.20. "Life Satisfaction Scale - (Köker, 1991)", "Communication Skills Scale (Korkut-Owen \& Bugay, 2014)" and "Personal Information Form" were used as data collection tools. The data obtained in the study were analyzed using the stepwise regression analysis method from multiple linear regression analysis. As a result of the research, it was determined that the variables of life satisfaction and communication skills significantly predicted academic achievement. It was observed that the variables of "life satisfaction" in the first place and "communication skills" in the second place significantly predicted the academic achievement of the teacher candidates.
\end{abstract}

Keywords: Academic achievement, communication skills, life satisfaction, teacher candidates.

\section{Introduction}

Academic success is an important criterion in determining the level of students to acquire certain knowledge and skills. Examinations held under different names in almost every level of education from primary school to university in Turkey, and educational and vocational orientations made according to the results of these exams, are an academic success center and an important center for students to have a good academic and professional future in this context. has place. Academic success is a factor that is considered important not only by the students but also by the students' environment (family, educators, administrators, etc.). It is known that academic success is a determining factor in personal and professional development (Ateş, 2016). From another point of view, academic success can be defined as an indicator of the level of students gaining certain knowledge and skills from academic courses according to a criterion.

When the literature is examined, it has been seen that academic success is related to variables such as hope (Ebrahimi et al., 2011), well-being (Beauvais et al., 2014), emotion regulation (Graziano et al., 2007), motivation (Luqman, 2013), emotional intelligence (Barchard, 2003; Beauvais et al., 2014; Parker et al.,

\footnotetext{
1 Assoc.Prof., Erzincan Binali Yıldırım University, Turkey, Faculty of Education, bunyaminates81@gmail.com, ORCID: 0000-0003-4090-1922

2 Ass. Prof., Afyon Kocatepe University, Turkey, Faculty of Education, mehmetenes15@gmail.com, ORCID: 00000003-0941-5301
} 
2004), resilience (Beauvais et al., 2014), metacognition (Coutinho, 2007), intelligence (Ridgell \& Lounsbury, 2004), academic efficacy (Edman \& Brazil, 2009) and self-control (Oriol et al., 2017). As in almost every level of education, academic success can be seen as an important criterion in determining the level of gaining certain knowledge and skills for teacher candidates who are in the university process. In this respect, it is thought that it is important to determine the variables related to academic success in teacher candidates and thus to be a source for studies aimed at increasing academic success. In this context, it is thought that the life satisfaction and communication skills of teacher candidates are related to their academic achievement and may be a significant predictor of academic success.

This concept was first introduced to the literature by Neugarten et al. (1961). It is explained as a personal evaluation or result that emerges by comparing one's expectations about life and what he has achieved. Life satisfaction is a cognitive component of subjective well-being; includes cognitive judgments about one's life (Diener, 1984). It can also be defined as a positive evaluation of one's whole life in the context of the criteria that one determines (Diener et al., 1985). At this point, what is meant by life satisfaction is not only the satisfaction of a particular situation; it can be understood as obtaining positive satisfaction from his whole life. In this context, life satisfaction can be expressed as the state of being satisfied with one's life by positively evaluating it as a whole. Since positivity prevails in the life of a teacher candidate with a high level of life satisfaction, it is thought that his academic success will be positively affected by this.

Another variable that is thought to be related to the academic achievement variable of teacher candidates in this study is communication skills. Communication is the transfer of a message or information from the sender to the receiver through a medium or channel. Communication is also expressed as a process in the context of the receiver giving feedback to the sender of the message. This process generally consists of four elements: source, receiver, communication channel and feedback (Sen, 2005). In other words, communication is the ability to interact between the informant and the informant through verbal and nonverbal methods (Chen \& Starosta, 1996; Seiler \& Beall, 2005). This shopping process that occurs in communication can be healthier with communication skills. These skills include understanding, being understood, conveying feelings and thoughts correctly, respecting etc. includes features. Communication skills are a skill that can be learned and developed. It is of great importance for people to develop their communication skills and to be able to use these skills effectively in order to maintain a higher quality of life (Johnson, 1996; Verdener, 1999). In this context, communication skills can be expressed as an important ability in terms of expressing information, feelings and thoughts in one's social life, and being able to understand and share with others. In the context of research, a teacher candidate is expected to have effective, high-level communication skills. Teacher candidates with effective communication skills may have a high level of cognitive competencies such as understanding, interpreting, reasoning, inference, and comprehension. In addition, a teacher candidate's effective communication skills enable her to act more assertively in reaching information, which can positively affect her academic success.

Considering the educational processes of the teacher candidates, it is necessary for the teacher candidates to be academically successful in many practical and theoretical courses. In order for a teacher candidate to be a competent teacher, it is critical that they have high-level knowledge and skills in their field. At this point, teacher candidates need to demonstrate a certain level of academic success in order to become a professionally competent teachers. In the literature review on academic success, it has been 
determined that there are studies in which academic success is examined together with different groups and variables. However, no study was found in which the variables of academic achievement, life satisfaction, and communication skills were examined together in teacher candidates. Therefore, this study is considered valuable and important in terms of the field. In this context, the aim of the study was to examine how much the variables of life satisfaction and communication skills predicted the academic achievement levels of teacher candidates. In the research conducted for this purpose, “Do the variables of life satisfaction and communication skills of teacher candidates significantly predict the academic achievement levels?" the answer to the question has been sought.

\section{Method}

\section{Research Model}

The research was based on the "relational screening model". The relational screening model is a model for determining the existence or degree of co-variation among variables (Karasar, 2016).

\section{Research Group}

The research group consisted of 398 teacher candidates (172 males, 226 females) studying at the education faculties of different universities in Turkey in the 2020-2021 academic year. The distribution of the research group in terms of gender is presented in the table below. The age range of the teacher candidates in the study is between 18-25; the average age was determined as 21.20.

\section{Table 1}

Distribution of the Research Group by Gender

\begin{tabular}{lll}
\hline Gender & $\mathrm{N}$ & $\%$ \\
\hline Male & 172 & 43.2 \\
\hline Female & 226 & 56.8 \\
\hline Total & 398 & 100 \\
\hline
\end{tabular}

\section{Data Collection Tools}

\section{Life Satisfaction Scale}

This scale was developed by Diener et al. (1985), and its Turkish adaptation was carried out by Köker (1991). The internal consistency coefficient of this five-item scale is .85. The increase in the total scores obtained from this seven-point Likert-type scale indicates that life satisfaction is high. In this study, the Cronbach Alpha reliability coefficient for the whole scale was determined to be .82 .

\section{Communication Skills Scale}

This scale, developed by Korkut-Owen and Bugay (2014), consists of twenty-five items. The Cronbach Alpha internal consistency coefficient of the scale was found to be .88 . High scores obtained from the scale indicate that communication skills increase. The score of each question in the scale varies between 
1 and 5 according to the answers "Never" and "Always". The lowest score obtained from the scale is 25, and the highest score is 125 . In this study, the Cronbach Alpha reliability coefficient for the entire scale was determined to be 92 .

\section{Personal Information Form}

The personal information form was created on the basis of the confidentiality principle within the scope of this research in order to learn the personal information of the teacher candidates who constitute the research group. Generall weighted grade point averages (GPA) in the quatrain system were taken as the basis in determining the academic success of teacher candidates.

\section{Collection of Data}

Research data were collected online via Google Form. In this direction, data collection tools prepared via Google Form were sent to teacher candidates via e-mail and they were invited to the research. The study was based on the participation of voluntary individuals. Informed consent was obtained from the individuals before participating in the study. In addition, the confidentiality principle was taken into account during the data collection process and individuals were informed about this issue. The online data collection process took approximately one week.

\section{Data Analysis}

It was determined that the data obtained depending on the examinations were suitable for multiple linear regression analysis. The data obtained in the study were analyzed with the multiple linear regression analysis (stepwise) method.

\section{Findings}

In the findings, part of the study, first the arithmetic mean and standard deviation values of the research group's academic achievement, life satisfaction, and communication skills scores, then the simple correlation analysis coefficients for the variables, and finally the multiple linear regression analysis (stepwise) results are given. The arithmetic mean and standard deviation values of the research group's academic achievement, life satisfaction, and communication skills scores are given in the table below.

\section{Table 2}

Arithmetic Mean and Standard Deviation Values

\begin{tabular}{lccc}
\hline Variable & $\mathrm{N}$ & $\bar{x}$ & $\mathrm{SD}$ \\
\hline Academic Achievement (A.C.) & 398 & 3.04 & .60 \\
\hline Life Satisfaction (L.S.) & 398 & 22.48 & 5.81 \\
\hline Communication Skills (C.S.) & 398 & 96.76 & 18.76 \\
\hline
\end{tabular}

When Table 2 is examined, the arithmetic mean and standard deviation values of the research group; academic achievement $(\bar{X}=3.04 ; \mathrm{SD}=.60)$, life satisfaction $(\bar{X}=22.48 ; \mathrm{SD}=5.81)$ and communication skills $(\bar{X}=96.76 ; \mathrm{SD}=18.76)$. The relationships between academic achievement, life satisfaction, and 
communication skills were examined using the simple correlation analysis method and the results are given in Table 3.

Table 3

Simple Correlation Analysis Coefficients for Variables

\begin{tabular}{|c|c|c|c|}
\hline Variable & A.C. & L.S. & C.S. \\
\hline Academic Achievement (A.C.) & 1 & & \\
\hline Life Satisfaction (L.S.) & $.565^{* *}$ & 1 & \\
\hline Communication Skills (C.S.) & $.403^{* *}$ & $.338^{* *}$ & 1 \\
\hline
\end{tabular}

** $p<.01$

When Table 3 is examined, it has been determined that there is a significant positive correlation between academic achievement and life satisfaction $(r=.565, p<.01)$ and communication skills $(r=.403, p<.01)$.

In the next step, when the ANOVA table, which tests the relationship of the predictor variables with the predicted variable and therefore the significance of the degree of explaining the change in the predicted variable, is examined, it has been determined that the explained variance or the regression model is statistically significant $\left(\mathrm{F}_{(1,396)}=186.14 ; \mathrm{F}_{(2,395)}=116.22, p<.01\right)$. Accordingly, the predictor variables successfully performed the prediction process on the model.

\section{Table 4}

Multiple Linear Regression Analysis (Stepwise) Results on Predicting Academic Achievement

\begin{tabular}{|c|c|c|c|c|c|c|c|c|c|c|}
\hline \multirow[t]{2}{*}{ Model } & \multicolumn{2}{|c|}{ UC } & \multicolumn{8}{|l|}{ SC } \\
\hline & $B$ & $\begin{array}{l}\text { Std. } \\
\text { Error }\end{array}$ & Beta & $t$ & $\begin{array}{l}\text { Zero- } \\
\text { Order }\end{array}$ & Partial & $R$ & $R^{2}$ & $F$ & $S d$ \\
\hline 1 (Constant) & 1.72 & .100 & & $17.14^{* *}$ & & & & & & \\
\hline L.S. & .059 & .004 & .565 & $13.64^{* *}$ & .565 & .565 & $.565^{\mathrm{a}}$ & .320 & $186.14^{* *}$ & $1 / 396$ \\
\hline 2 (Constant) & 1.16 & .138 & & $8.40^{* *}$ & & & & & & \\
\hline L.S. & .051 & .004 & .485 & $11.42^{* *}$ & .565 & .499 & $.609^{b}$ & .370 & $116.22^{* *}$ & $2 / 395$ \\
\hline C.S. & .008 & .001 & .239 & $5.64^{* *}$ & .403 & .273 & & & & \\
\hline
\end{tabular}

${ }^{* *} p<.01$, UC (Unstandardized Coefficients), SC (Standardized Coefficients)

When Table 4 was examined, it was determined that the variables of life satisfaction and communication skills were included in the multiple linear regression analysis (stepwise) process, as they predicted academic achievement significantly. When both beta and correlation (zero-order/partial) values were 
examined, it was determined that there was a significant positive correlation between the academic achievement variable and the life satisfaction and communication skills variables. Life satisfaction and communication skills variables together explain $37 \%$ of the total variance $\left(R=.609 ; R^{2}=.370, p<.01\right)$ regarding the academic achievement of teacher candidates.

The beta coefficient of the life satisfaction variable examined in the first step of the stepwise regression analysis in predicting academic success is .565. It was determined that the t-test result regarding the significance of the beta coefficient was at a significant level $(t=13.64, p<.01)$. The life satisfaction variable alone explains $32 \%$ of academic achievement $\left(R=.565 ; R^{2}=.320\right)$.

In the second step of the stepwise regression analysis, besides the life satisfaction variable, the communication skills variable was also included in the model. When other variables affecting life satisfaction are kept constant, life satisfaction and communication skills variables together explain 37\% of academic success $\left(R=.609 ; R^{2}=.370\right)$. When other variables in the model are kept constant, the beta coefficient of the life satisfaction variable is .485 and the beta coefficient of the communication skills variable is .239. It was determined that the t-test results regarding the significance of the beta coefficient were at a significant level $\left(t_{\mathrm{LS}}=11.42, p<.01 ; t_{\mathrm{CS}}=5.64, p<.01\right)$.

Considering the beta coefficients of the variables included in the model in the third step and the t-test results regarding the significance of the beta coefficients, it was seen that the variables of life satisfaction and communication skills significantly predicted academic achievement. Considering the beta values of the variables in the model, it was determined that the academic achievement of the teacher candidates was significantly predicted by the "life satisfaction" variables in the first place and the "communication skills" variables in the second place. In other words, the relative importance of the predictor variables on academic achievement is life satisfaction and communication skills.

\section{Discussion}

According to the results of the research, it was determined that there is a positive and significant relationship between academic achievement, life satisfaction, and communication skills. In addition, it was determined that the variables of life satisfaction and communication skills were significant predictors of the academic achievement variable. Life satisfaction and communication skills variables together explain $37 \%$ of the total variance in the academic success of teacher candidates. As a result of the research, "life satisfaction" and "communication skills" variables significantly predicted the academic success of teacher candidates, respectively.

Academic success can be expressed as a term that is frequently used in activities, research, measurement, and evaluation processes, especially in higher education. Academic success can also be defined as the success achieved as a result of evaluating the knowledge and skills expected from the student in the context of a certain criterion in the education process. Academic success, which has a place in every stage of education life, is undoubtedly very important for university students in higher education. Therefore, as academic success has an important place for all university students, it is also of great importance for teacher candidates. It is a serious prerequisite for teacher candidates to be successful academically, to gain professional equipment, and to be good educators in their later life. At this point, the academic achievements of teacher candidates have a functional place both in their 
education processes and in their professional development and being successful teachers. In this context, the fact that teacher candidates can achieve academic success and be professionally equipped will be reflected in other areas of their lives and will help them achieve success in different areas. For these reasons, it can be said that determining the variables related to academic achievement in teacher candidates can make significant contributions to awareness and knowledge. Accordingly, in this study, the relationship between life satisfaction and communication skills variables in teacher candidates' academic achievement and their predictive power were discussed.

As a result of this study, it was seen that the academic success of teacher candidates was predicted in the first place by the variable of life satisfaction and there was a significant positive relationship between them. Based on this result, it can be said that as the life satisfaction level of teacher candidates increases, the level of academic achievement also increases. Life satisfaction is a person's happiness, well-being, and positive evaluation of his life. It is expressed as a positive evaluation of the whole life or quality of life in the context of the criteria that a person has created (Diener, 1984; Diener, 1995; Diener et al., 1985; Diener \& Suh, 1997; Neugarten et al., 1961). Therefore, it can be stated that positive perceptions of a person's life also have a positive effect on mental health. It can be said that a person's good mental health can be reflected in every area of his life. In this context, it is thought that life satisfaction will undoubtedly play an important role in the achievement of education and training, which has an important place in life, and the related academic success. As a matter of fact, $\mathrm{Ng}$ et al. (2015) point out that although students' subjective well-being is closely related to positive school outcomes, it is a neglected issue. In addition, it emphasizes the need to determine the role of students' subjective wellbeing and especially global life satisfaction on academic success, since academic achievement is a widely used criterion in student success and school responsibility. Based on this information, it is thought that the same need exists for teacher candidates. In addition, Arenas and Man (2020) state that a positive education requires the pursuit of happiness and well-being to inspire and assist the progress of students, schools, and communities. In this context, he emphasizes that the relationship between academic achievement and life satisfaction should be addressed. As a result of this research carried out within this framework, it was found that as the academic achievement level of teacher candidates increases, the level of life satisfaction also increases. In addition, this result obtained from the research supports the current research results in the literatüre (Abolghasemi \& Varaniyab, 2010; Crede et al., 2015; Kirkcaldy et al., 2004; Suldo et al., 2006). In another study by Antaramian (2017), individuals with very high life satisfaction were compared with those with average and low life satisfaction to investigate the differences in academic factors. The results revealed that both groups were satisfied with life. However, it has been determined that individuals with high life satisfaction have more student participation, academic self-efficacy, and approach-oriented success. It has also been found that these individuals experience lower academic stress and have a higher Grade Point Average (GPA) than their peers. The result obtained from this study supports the result obtained by Antaramian (2017). In the study conducted by Datu and Bernardo (2020), the finding that there is a relationship between general academic achievement and life satisfaction is consistent with the result of this study. In another study by Moussa and Ali (2021), it is emphasized that students with academic success have a high level of happiness. The result obtained from this study indirectly supports the finding that the academic success of the students and their happiness levels are related. Contrary to all the findings in the literature, in the study conducted by García-Martínez et al. (2021), it was determined that emotional intelligence and resilience directly predicted students' life satisfaction. However, it has been determined that this direct 
relationship did not result in academic performance. García-Martínez et al. (2021) state that this finding is one that has not been found until now. In addition, they found that participation plays an indirect mediating role on both life satisfaction and academic performance of students. When the result of this study and other available results are evaluated together, it can be said that the higher the life satisfaction level of the person, the higher the academic success. In other words, it can be stated that life satisfaction can contribute positively to academic success. In this context, it can be said that a high level of life satisfaction has an important function in increasing the academic success level of teacher candidates.

Within the scope of this study, it was seen that academic achievement was significantly predicted by the variable of communication skills after the variable of life satisfaction, and there was a significant positive correlation between them. In other words, it can be said that as the level of communication skills of teacher candidates increases, the level of academic achievement also increases. Communication skills deal with processes such as conveying one's feelings and thoughts correctly, understanding the other person correctly, and understanding the other person correctly. Gaining communication skills is considered very important in terms of communicating effectively and exchanging ideas with one's environment. This situation is necessary in terms of quality of life (Downey, 1977; Johnson, 1996; Verdener, 1999). Therefore, having effective communication skills in one's life can be considered as a key point in communicating effectively with the environment. In addition, it can be stated that effective communication skills and positive harmony with one's environment can contribute positively to mental health. It can be said that a person's good communication skills can be reflected in every area of his life. In this context, it is thought that effective communication skills will undoubtedly play an important role in the relations in education life, which has an important place in life, and in achieving academic success related to it. As a matter of fact, Yahaya and Nordin (2006) emphasize that the current trends in the education system, where students' ability to express themselves in the education process is at the forefront, is a necessity for students to acquire communication skills. It also draws attention to the fact that students who lack communication skills will experience both communication and academic problems. Based on this information, it is thought that the same obligation or even more is in question for teacher candidates. This idea is also emphasized by Khan et al. (2017) as teacher communication skills have an important role in students' academic success. Similarly, Obilor (2020) points out that teachers' communication skills have an impact on students' academic performance. Therefore, teachers with communication skills can both be a model for students and benefit students' academic success. In this study carried out within this framework, it was concluded that as the level of communication skills of teacher candidates increases, the level of academic achievement also increases. In addition, this result obtained from the research supports the current research results in the literature (Jeon \& Park, 2014; Yahaya \& Ramli, 2009; Talebi Khansari, 2020). In addition, the result of the study conducted by Hawken et al. (1991) that communication competence and academic achievement are related is consistent with the result of this study. Similarly, in the results of this research, it was determined that there was a positive and significant relationship between academic achievement and communication skills. In another study conducted by Jovarini et al. (2018), the finding that social skills such as assertiveness, empathy, and emotional approach predict student's academic success seems to be compatible with the result of this study. When the result of this study and other available results are evaluated together, it can be said that the higher the communication skills level of the person, the higher the academic success. In this direction, it can be said that raising the level of communication skills has an important function in increasing the academic achievement levels of teacher candidates. In addition, it can be said that studies 
to increase the level of communication skills of teacher candidates can help to increase their academic achievement levels.

Based on the results of this research conducted with teacher candidates, it can be stated that teacher candidates with high life satisfaction and communication skills have a high level of academic success. In line with the results obtained from this study, some suggestions are given below:

As a result of this study, life satisfaction and communication skills variables together explain $37 \%$ of the total variance regarding the academic success of teacher candidates. In order to increase academic success, experimental studies that will increase the life satisfaction and communication skills of teacher candidates can be included. In future studies, the variable of academic achievement can be examined together with different variables.

In this study, the research group is limited to teacher candidates. Another study can be conducted on different sample groups (professional candidates studying at different faculties, adolescents, adults, different heterogeneous groups, etc.).

As a result of the study, it was concluded that as the level of life satisfaction and communication skills of teacher candidates increases, the level of academic achievement also increases. In this direction, studies that will increase the level of life satisfaction and communication skills of teacher candidates can be included in increasing their academic success. In addition to academic success, faculty members can carry out studies that emphasize educational activities, life satisfaction, and communication skills.

\section{References}

Abolghasemi, A., \& Varaniyab, S. T. (2010). Resilience and perceived stress: Predictors of life satisfaction in the students of success and failure. Procedia-Social and Behavioral Sciences, 5(2010), 748-752. https://doi.org/10.1016/j.sbspro.2010.07.178.

Antaramian, S. (2017). The importance of very high life satisfaction for students' academic success. Cogent Education, 4(1), 1-10. DOI: 10.1080/2331186x.2017.1307622.

Arenas, J. C., \& Man, Y. K. (2020). Academic achievement and life satisfaction of students in Mathematics in positive education intervention. The International Journal of Social Sciences and Humanities Invention, 7(4), 5910-5918. DOI: 10.18535/ijsshi/v7i04.04.

Ateş, B. (2016). Üniversite öğrencilerinde akademik başarının yordayıcısı olarak psikolojik iyi oluş ve sosyal yetkinlik. Elektronik Sosyal Bilimler Dergisi, 15(59), 1203-1214. DOI: 10.17755/esosder.86299.

Barchard, K. A. (2003). Does emotional intelligence assist in the prediction of academic success? Educational and Psychological Measurement, 640-858. https://doi.org/10.1177/0013164403251333.

Beauvais, A. M., Stewart, J. G., DeNisco, S., \& Beauvais, J. E. (2014). Factors related to academic success among nursing students: A descriptive correlational research study. Nurse education today, 34(6), 918-923. DOI: 10.1016/j.nedt.2013.12.005. 
Chen, G. M., \& Starosta, W. J. (1996). Intercultural communication competence: A synthesis. In B. R. Burleson (Ed.), Communication yearbook 19 (pp. 353-383). Thousand Oaks, CA: Sage.

Coutinho, S. A. (2007). The relationship between goals, metacognition, and academic success. Educate , 7(1), 39-47.

Crede, J., Wirthwein, L., McElvany, N., \& Steinmayr, R. (2015). Adolescents' academic achievement and life satisfaction: The role of parents' education. Frontiers in Psychology, 6(52), 1-8. https://doi.org/10.3389/fpsyg.2015.00052.

Datu, J. A. D., \& Bernardo, A. B. (2020). The blessings of social-oriented virtues: Interpersonal character strengths are linked to increased life satisfaction and academic success among Filipino high school students. Social Psychological and Personality Science, 11(7), 983-990. https://doi.org/10.1177/1948550620906294.

Diener, E. (1984). Subjective well-being. Psychological Bulletin, 95(3), 542575. https://doi.org/10.1037/0033-2909.95.3.542.

Diener, E. (1995). A value based index for measuring national quality of life. Social indicators research, 36(2), 107-127. https://doi.org/10.1007/BF01079721.

Diener, E., \& Suh, E. (1997). Measuring quality of life: Economic, social, and subjective indicators. Social indicators research, 40(1), 189-216. https://doi.org/10.1023/A:1006859511756.

Diener, E. D., Emmons, R. A., Larsen, R. J., \& Griffin, S. (1985). The satisfaction with life scale. Journal of Personality Assessment, 49(1), 71-75. DOI: 10.1207/s15327752jpa4901_13.

Downey, M. E. (1977). Interpersonal judgements in education. London: Harper \& Row.

Ebrahimi, N., Sabaghian, Z., \& Abolghasemi, M. (2011). Investigating relationship of hope and academic success of college students. Quarterly journal of research and planning in higher education, 17(2), 116. http://journal.irphe.ac.ir/article-1-1187-en.html.

Edman, J. L., \& Brazil, B. (2009). Perceptions of campus climate, academic efficacy and academic success among community college students: An ethnic comparison. Social Psychology of Education, 12(3), 371-383. https://doi.org/10.1007/s11218-008-9082-y.

García-Martínez, I., Landa, J. M. A., \& León, S. P. (2021). The Mediating Role of Engagement on the Achievement and Quality of Life of University Students. International Journal of Environmental Research and Public Health, 18(12), 6586-6597. https://doi.org/10.3390/ijerph18126586.

Graziano, P. A., Reavis, R. D., Keane, S. P., \& Calkins, S. D. (2007). The role of emotion regulation in children's early academic success. Journal of school psychology,45(1), 3-19. DOI: 10.1016/j.jsp.2006.09.002.

Hawken, L., Duran, R. L., \& Kelly, L. (1991). The relationship of interpersonal communication variables to academic success and persistence in college. Communication Quarterly, 39(4), 297-308. https://doi.org/10.1080/01463379109369807.

Jeon, S., \& Park, J. H. (2014). Analysis of relationships of scientific communication skills, science process skills, logical thinking skills, and academic achievement level of elementary school 
students. Journal of the Korean Association for Science Education,34(7), 647-655. DOI: 10.14697/JKASE.2014.34.7.0647.

Johnson, D. W. (1996). Reaching out: Interpersonal effectiveness and self-actualization. (6 ${ }^{\text {th }}$ ed.) Boston, Allyn and Bacon.

Jovarini, N. V., Leme, V. B. R., \& Correia-Zanini, M. R. G. (2018). Influence of social skills and stressors on academic achievement in the sixth-grade. Paidéia (Ribeirão Preto), 28(0), 1-9. DOI: 10.1590/1982$4327 \mathrm{e} 2819$.

Karasar, N. (2016). Bilimsel araştırma yöntemi. (31. Basım). Ankara: Nobel Akademik Yayıncılık.

Khan, A., Khan, S., Zia-Ul-Islam, S., \& Khan, M. (2017). Communication skills of a teacher and its role in the development of the students' academic success. Journal of Education and Practice, 8(1), 18-21. Corpus ID: 152003904.

Kirkcaldy, B., Furnham, A., \& Siefen, G. (2004). The Relationship between Health Efficacy, Educational Attainment, and Well-Being among 30 Nations. European Psychologist, 9(2), 107-119. DOI: 10.1027/1016-9040.9.2.107.

Köker, S. (1991). Normal ve sorunlu ergenlerin yaşam doyumu düzeylerinin karşılaştırılması. (Master's thesis). Retrieved from YÖK Thesis Center (Thesis No: 16802).

Korkut-Owen, F., \& Bugay, A. (2014). İletişim Becerileri Ölçeği'nin geliştirilmesi: geçerlik ve güvenirlik çalışması. Mersin Üniversitesi Ĕ̆itim Fakültesi Dergisi, 10(2), 51-64. Retrieved from https://dergipark.org.tr/tr/pub/mersinefd/issue/17394/181805.

Luqman, M. (2013). Relationship of academic success of medical students with motivation and preadmission grades. Journal of the College of Physicians and Surgeons Pakistan, 23(1), 31-36. PMID: 23286620 .

Moussa, N. M., \& Ali, W. F. (2021). Exploring the Relationship between Students' Academic Success and Happiness Levels in the Higher Education Settings during the Lockdown Period of COVID-19. Psychological Reports, 0(0), 1-25. DOI: 10.1177/0033294121994568.

Neugarten, B. L., Havighurst, R. J., \& Tobin, S. S. (1961). The measurement of life satisfaction. Journal of Gerontology, 16(2), 134-143. DOI: 10.1093/geronj/16.2.134.

Ng, Z. J., Huebner, S. E., \& Hills, K. J. (2015). Life satisfaction and academic performance in early adolescents: Evidence for reciprocal association. Journal of school psychology, 53(6), 479-491. http://dx.doi.org/10.1016/j.jsp.2015.09.004.

Obilor, E. I. (2020). Teachers' communication skills and students' academic performance. International Journal of Advanced Academic and Educational Research, 13(4), 28-41.

Oriol, X., Miranda, R., Oyanedel, J. C., \& Torres, J. (2017). The role of self-control and grit in domains of school success in students of primary and secondary school. Frontiers in Psychology, 8(1716), 1-9. https://doi.org/10.3389/fpsyg.2017.01716. 
Parker, J. D., Summerfeldt, L. J., Hogan, M. J., \& Majeski, S. A. (2004). Emotional intelligence and academic success: Examining the transition from high school to university. Personality and individual differences, 36(1), 163-172. DOI: 10.1016/S0191-8869(03)00076-X.

Ridgell, S.D., \& Lounsbury, J.W. (2004). Predicting academic success: General intelligence, Big Five personality traits, and work drive. College Student Journal, 38(4), 607-619.

Seiler, W. J., \& Beall, M. L. (2005). Communication: making connections. Pearson/Allyn and Bacon.

Sen, L. (2005). Communication skills. New Delhi: Prentice-Hall of India Private Limited.

Suldo, S. M., Riley, K. N., \& Shaffer, E. J. (2006). Academic correlates of children and adolescents' life satisfaction. School Psychology International, 27(5), 567-582. https://doi.org/10.1177/0143034306073411.

Talebi Khansari, L. (2020). Relationship between classroom management practices and communication skills with academic achievement motivation of primary school students in Chabaksar. Management and Educational Perspective, 2(3), 113-131. DOI: 10.22034/JMEP.2020.243991.1030.

Verdener, R. F. (1999). Communicate! (9th Ed). Belmont CA: Wadsworth Publishing Company.

Yahaya, A., \& Nordin, K. (2006). Relationship between self concepts, motivation, and parenting styles effected Students Achievements. (Unpublished article). Retrieved from Universiti Technology Malaysia (ID No: 5911).

Yahaya, A., \& Ramli, J. (2009). The relationship between self-concept and communication skills towards academic achievement among secondary school students in Johor Bahru. International Journal of Psychological Studies, 1(2), 25-34. DOI: 10.5539/ijps.v1n2p25. 